\title{
STUDIO TEATER PANGGUNG BONEKA SEBAGAI SARANA PEMBELAJARAN PAUD DI KOTA PALOPO
}

\author{
Eka Poppi Hutami \\ Institut Agama Islam Negeri Palopo \\ Email : ekapoppihutami@gmail.com
}

Orcid id : https://orcid.org/0000-0002-9182-6662

Syamsul Alam Ramli

STKIP Muhammadiyah Palopo

Email : syamsulalamramli@gmail.com

Orcid id : https://orcid.org/0000-0003-1039-4878

Article received: 20 Agustus 2018, Review process: 21 Agustus 2018

Article published: 30 September 2018

\begin{abstract}
The background of this study is PAUD learning facilities owned by PAUD institutions in kindergarten are still limited in Palopo City. This study aims to be able to develop a Theater Theater for Dolls as a Means of PAUD Learning in Palopo City. This development research uses the Mix Method Approach using the Reseach and Devolution method. The development results are based on three things, namely production design, interior and exterior design, and learning design. The development began with Preliminary Study, Designing and developing products, product trials, and up to Commercialization of Applications. The Puppet Stage Theater Studio is an entire stage in the form of a space and inside there is a place to play dolls, settings and areas to perform puppet shows. The Puppet Stage Theater Studio can make pupils can play puppets in the theater studio and actualize themselves through puppet games in puppet shows. The Puppet Stage Theater Studio can be used as an alternative to Educative Game Tools as a means of Teaching PAUD and its development according to the standards of PAUD Learning Facilities in Kindergarten in Palopo City.
\end{abstract}

Keywords: Theater Studio, Puppet Stage, PAUD Learning Facility

\begin{abstract}
Abstrak
Penelitian ini melatarbelakangi sarana pembelajaran PAUD yang dimiliki lembaga PAUD di Taman Kanak-kanak masih terbatas di Kota Palopo. Penelitian ini bertujuan untuk dapat mengembangkan Studio Teater Panggung Boneka Sebagai Sarana Pembelajaran PAUD di Kota Palopo. Penelitian pengembangan ini menggunakan Pendekatan Mix Method dengan menggunakan metode Reseach and Devolopment. Hasil pengembanganya didasari dengan tiga hal yaitu desain produksi, desain interior dan eksterior, dan desain pembelajaran. Pengembangannya diawali Studi Pendahuluan, Merancang dan mengembangkan produk, Uji coba produk, dan sampai dengan Komersialisasi Pengaplikasian. Studio Teater Panggung Boneka adalah seluruh panggung yang berbentuk ruang dan didalamnya terdapat tempat untuk memainkan boneka, latar dan area untuk mementaskan pertunjukan boneka. Studio Teater Panggung Boneka dapat menjadikan anak didik dapat bermain boneka di dalam studio teater dan mengaktualisasikan dirinya melalui permainan boneka pada pertunjukan boneka. Studio Teater Panggung Boneka dapat dijadikan alternatif Alat Permainan Edukatif sebagai Sarana
\end{abstract}


Pembalajaran PAUD serta pengembanganya sesuai standar Sarana Pembelajaran PAUD di Taman Kanak-kanak Kota Palopo.

Kata Kunci : Studio Teater, Panggung Boneka, Sarana Pembelajaran PAUD.

\section{PENDAHULUAN}

Kota Palopo dengan latar belakang kultur dan budaya diibaratkan sebagai salah kota hinterland dengan macam suku, agama dan budaya yang berbeda-beda. Jumlah penduduk Kota Palopo telah mencapai 172.332 jiwa, terdiri dari laki-laki sebanyak 86.401 jiwa dan perempuan sebanyak 85.931 jiwa yang tersebar tidak merata. Begitu juga dengan Satuan Program Pendidikan Anak usia Dini atau yang dikenal PAUD di Kota Palopo memberikan layanan PAUD yang diselenggarakan lembaga-lembaga PAUD yang berbentuk TK, RA, BA, KB, TPA, SPS. Dari sembilan kecamatan yaitu TK/RA berjumlah 96, KB berjumlah 32, TPA berjumlah 4, SPS berjumlah 2. Secara keseluruhan satuan PAUD di Kota Palopo berjumlah 134.

Selain Makassar dan Pare-pare, kota Palopo kini sedang tumbuh dan berkembang sebagai kota jasa terkemuka terutama dalam dunia Pendidikan Anak Usia Dini di Lembaga PAUD. Layanan tersebut diberikan untuk menunjang peningkatan akses dan mutu layanan PAUD di Kota Palopo. Walaupun kebijakan dalam pembinaan PAUD telah ditetapkan dalam Peraturan Menteri, namun kenyataannya belum semua lembaga-lembaga PAUD terutama Taman Kanak-kanak melayani semua anak terlayani PAUD di Kota Palopo. Hal ini jumlah anak yang terlayani PAUD di Kota Palopo disebabkan 1) orang tua anak belum menyadari pentingnya PAUD, mereka hanya menganggap PAUD adalah tempat bermain, 2) kondisi ekonomi yang membuat orang tua tidak dapat kesempatan menyekolahkan anaknya di PAUD 3) tidak meratanya lembaga PAUD di sembilan Kecamatan, 4) terbatasnya lembaga PAUD memberikan layanan, 5) kesejahteraan guru PAUD belum memenuhi kebutuhan standar ekonomi, 6) terbatasnya sarana dan prasarana pembelajaran yang dimiliki lembaga PAUD.

Berdasarkan hal tersebut, pemerintah melalui Dirjen PAUD telah mengalokasikan Bantuan Sarana Pembelajaran PAUD. Sarana pembelajaran PAUD adalah seperangkat bahan dan media belajar untuk mendukung kegiatan belajar melalui bermain sehingga dapat mengoptimalkan perkembangan anak (Dirjen PAUD, 2018). Namun bantuan tersebut diperuntukan bagi lembaga PAUD yang dinilai mempunyai potensi untuk menjadi pusat dalam pengembangan sarana pembelajaran di lembaga satuan PAUD yang ada diwilayahnnya 
(Dirjen PAUD, 2018:2). Untuk itu lembaga PAUD diwilayahnya yang tidak dapat mendapatkan bantuan, dapat membuat dan mengembangkan sarana pembelajaran di lembaga PAUD.

Kondisi ini lembaga PAUD dituntut untuk dapat mengembangkan sarana pembelajarannya untuk menunjang peningkatan akses dan mutu layanan PAUD di Kota Palopo. Seels \& Richey menjelaskan pengembangan yang dimaksud adalah usaha sadar dan terencana dalam merancang desain pembelajaran dalam bentuk fitur fisik (Alim Sumarno, 2012). Selain itu pengembangan dapat digunakan untuk menyalurkan informasi atau materi pengajaran melalui melalui indera pandang (visual) dan indera pandang-dengar (audio visual) yang dapat merangsang pikiran, perasaan, perhatian dan minat belajar (Ramli, Syamsul Alam, 2014).

Model pengembangan harus berdasarkan standar kriteria persyaratan pendukung penyelenggaraan dan pengelolaan PAUD secara Holistik dan Integratif yang tertuang pada Peraturan Mentri No. 137 Tahun 2014 dengan syarat bahwa perlengkapan dalam penyelenggaraan dan pengelolaan kegiatan pendidikan, pengasuhan dan perlindungan pada anak usia dini di PAUD merupakan standar sarana dan prasarana.

Sarana pembelajaran yang dimaksud pada permainan boneka masih terbatas dan area drama belum berdasarkan pada standar sarana pembelajaran PAUD. Pada permainan boneka adalah hal yang sering digemari oleh anak-anak bahkan orang dewasa pun suka bermain boneka. Bermain boneka merupakan cara yang terbaik anak melakukan kegiatan yang disenangi anak. Kegiatan tersebut merupakan kegiatan hal yang menyenangkan pada anak didik. Menurut Anita Yus (2012) bahwa bermain adalah kegiatan pembelajaran yang disukai dan sangat disenangi anak didik. Jika bermain boneka itu sangat disukai dan sangat disenangi anak didik, maka permainan boneka dapat dijadikan sebagai sistem pembelajaran alternatif pada kegiatan bermain boneka di PAUD. Untuk itu diperlukan sarana pembelajaran PAUD secara Holistik dan Integratif dan diharapkan pada permainan boneka dapat menunjang peningkatan akses dan mutu layanan PAUD di Kota Palopo.

Ditinjau dari praktisi pendidikan NAECY menjalaskan bahwa bermain boneka pada anak dapat (a) menjelajahi dunia, (b) mengembangkan pengetahuan sosial dan kultural, (3) mengungkapkan buah pikir dan emosi, (4) kesempatan mengalami dan memecahkan masalahnya sendiri, (5) mengembangkan keterampilan berbahasa dan melek huruf, serta mengembangkan pengertian dan konsep (Montolalu, dkk, 2005:1.11). Mereka menyadari 
bahwa melalui permainan boneka tangan atau pupet anak diajak melakukan kegiatan dalam mengembangkan kemampuan yang ada dalam dirinya. Mereka mengatakan boneka yaitu marionette dalam bahasa Perancis menjelaskan bahwa: a). Tubuh yang dihubungkan dengan lengan, kaki dan badannya, digerakkan dari atas dengan tali-tali atau kawat-kawat halus; b). Boneka yang digerakkan dari bawah oleh seorang yang tangannya dimasukkan ke bawah pakaian boneka (Sudjana \& Rivai,2007). Boneka yang yang dimaksud yaitu boneka jari, boneka tangan, boneka pupet, boneka tali, boneka wayang.

Permainan boneka ini banyak diperhatikan para praktisi dalam mengembangkan model permainan boneka dengan membuat sarana pembelajaran PAUD yakni tempat khusus yang berisikan boneka barbie, seperti Penelitian interior House of Barbie oleh Condroadi, Natalivea (2009) sebuah rumah yang memberikan informasi seputar boneka Barbie dan mengembangkan kreatifitas pengunjungnya. Rumah berbie menjadikan sebuah alasan untuk memberikan pengetahuan dan pengalaman anak yang berarti bahwa bermain boneka dapat divisualisasikan dalam Rumah Barbie. Ketersediaan rumah berbie dalam permainan boneka di lembaga PAUD pada kegiatan proses belajar mengajar tergolong minimnnya ketersediaaan APE (Alat Pemainan Edukatif) dikarenakan sarana dan prasarana yang terbatas. APE PAUD adalah sesuatu yang digunakan sebagai sarana bermain AUD yang mengandung nilai pendidikan dan dapat mengoptimalkan perkembangan anak (Dirjen PAUD, 2016:3)

Untuk itu praktisi pendidikan merancang alat permainan edukatif. Rancangan Aniendya Christianna, (2013:7-13) mengembangkan kegiatan pelatihan yang bertujuan mendorong Guru PAUD untuk merancang APE dari bahan yang murah dan mudah didapat. Kegiatan ini dirancang selama kebutuhan dan dibuat sebagai sumber belajar pada anak usia dini.

Ditinjau dari perspektif distribusi Pembelajaran Edukatif yang di desain dalam bentuk media pembelajaran. Media pembelajaran yang dimaksud berbasis panggung dan dikembangkan di lembaga PAUD pada materi-materi pembelajaran sastra dalam Kurikulum 2013 yang di representasikan ke dalam performa drama (Hari Sunaryo, dkk., 2016). Representasi kegiatan pembelajaran bermain drama melalui rangsangan kegiatan yang dihasilkan panggung cerita dapat memberikan pengaruh terhadap perkembangan anak. Pada lingkup perkembangan Nur Fathonah dan Erlin Ladyawati (2016) merancang metode permainan panggung cerita yang dikemas menarik hingga menjadi hal yang menyenangkan. 
Seiring perkembangan teknologi, panggung cerita dikembangkan didasari atas perbaikan aplikasi yang ada (J.Bessant, 1991: Bessant dan Rush, 1995:104). Perbaikan tersebut dilakukan melalui inovasi baru yang berbasis Studio Teater. Kata Studio berarti ruang yang dipakai untuk menyiarkan atau mementaskan, sedang kata Teater berarti ruang tempat pementasan atau pertunjukan drama sebagai suatu seni (KBBI,2018). Jadi studio teater adalah sebuah ruang kotak besar persegi panjang yang dipakai untuk mementaskan pertunjukan.

Berdasarkan temuan tersebut cenderung berfokus dalam mencari dan menemukan formulasi pembelajaran baru tanpa memperhatikan permasalahan yang terjadi di lembaga PAUD yaitu terbatasnya sarana pembelajaran PAUD yang dimiliki lembaga PAUD. Sarana Pembelajaran PAUD yang dimaksud adalah seperangkat alat dan bahan yang digunakan untuk menunjang proses pembelajaran pada anak usia dini, meliputi bahan belajar, media belajar, alat permainan dan alat peraga (Dirjen PAUDNI, 2013:5). Tidak tersedianya sarana pembelajaran PAUD menimbulkan pengaruh pada perkembangan belajar anak. Untuk memaksimalkan diperlukan adanya solusi alternatif yang dapat dipecahkan dengan cara peneliti mengemas dengan mengembangkan APE sebagai sarana pembelajaran PAUD di Taman Kanak-kanak. APE yang dimaksud adalah Studio Teater Panggung Boneka.

Studio Teater Panggung Boneka adalah seluruh panggung yang berbentuk ruang dan didalamnya terdapat tempat untuk memainkan boneka, latar dan area untuk mementaskan pertunjukan boneka dengan tujuan dapat menjadikan anak didik dapat bermain boneka di dalam studio teater dan mengeksplorasi dirinya melalui permainan boneka pada pertunjukan boneka. Eksplorasi tersebut dapat melatih keterampilan komunikasi anak muda menyampaikan ide dan gagasannya secara langsung (Sodian dalam Rustan, 2018:14). Untuk itu, peneliti mengemas dengan membuat rancangan dalam bentuk Studio Teater Panggung Boneka Sebagai Sarana Pembelajaran PAUD yang dapat dimanfaatkan anak didik dalam permainan boneka. Manfaat penelitian ini untuk 1) meningkatkan akses dan mutu layanan PAUD, 2) meningkatkan kemampuan lembaga PAUD dalam penyediaan dan pengembangan sarana pembelajaan dengan memanfaatkan bahan dan budaya lokal di Kota Palopo.

\section{METODOLOGI}

Penelitian ini menggunakan Pendekatan Mix Method dengan menggunakan metode Reseachh and Devolopment. Adapun sasaran penelitian dalam populasi ini adalah seluruh 
Satuan PAUD yang berada di Kota Palopo dengan subjek anak didik Kelompok usia 5-6 tahun atau Kelas Kelompok B.

Teknik penarikan sampel dari suatu populasi mengacu kriteria yaitu situasi dan karakteristik Satuan PAUD yaitu Taman Kanak-kanak tersebut yang tidak jauh berbeda dengan Taman kanak-kanak lainnya yang memiliki kesempatan yang sama untuk sebagai sampel. Metode pengambilan sampel diperoleh dengan multistage sampling Handini, (2012:52) dengan teknik purposive sampling yaitu populasi dibagi menjadi kelompok Taman Kanak-kanak berdasarkan tingkat akreditasi sekolah, kemudian ditarik satu Taman Kanakkanak yang mewakili, dari satu Taman Kanak-kanak dibagi dipilih secara acak berdasarkan usia 5-6 tahun, selanjutnya terpilih Kelompok B Usia 5-6 Tahun sebagai sampel. Rencana pengembangan penelitian ini diadopsi dari Borg dan Gall (1983: 772) yang dimodifikasi menjadi 4 langkah utama yaitu (1) Studi Pendahuluan, (2) Merancang dan mengembangkan produk, (3) Uji coba produk, dan (4) Komersialisasi Pengaplikasian Studio Teater Panggung Boneka. Berikut prosedural pengembangan Studio Teater Panggung Boneka dapat dilihat pada Gambar 1 sebagai berikut:

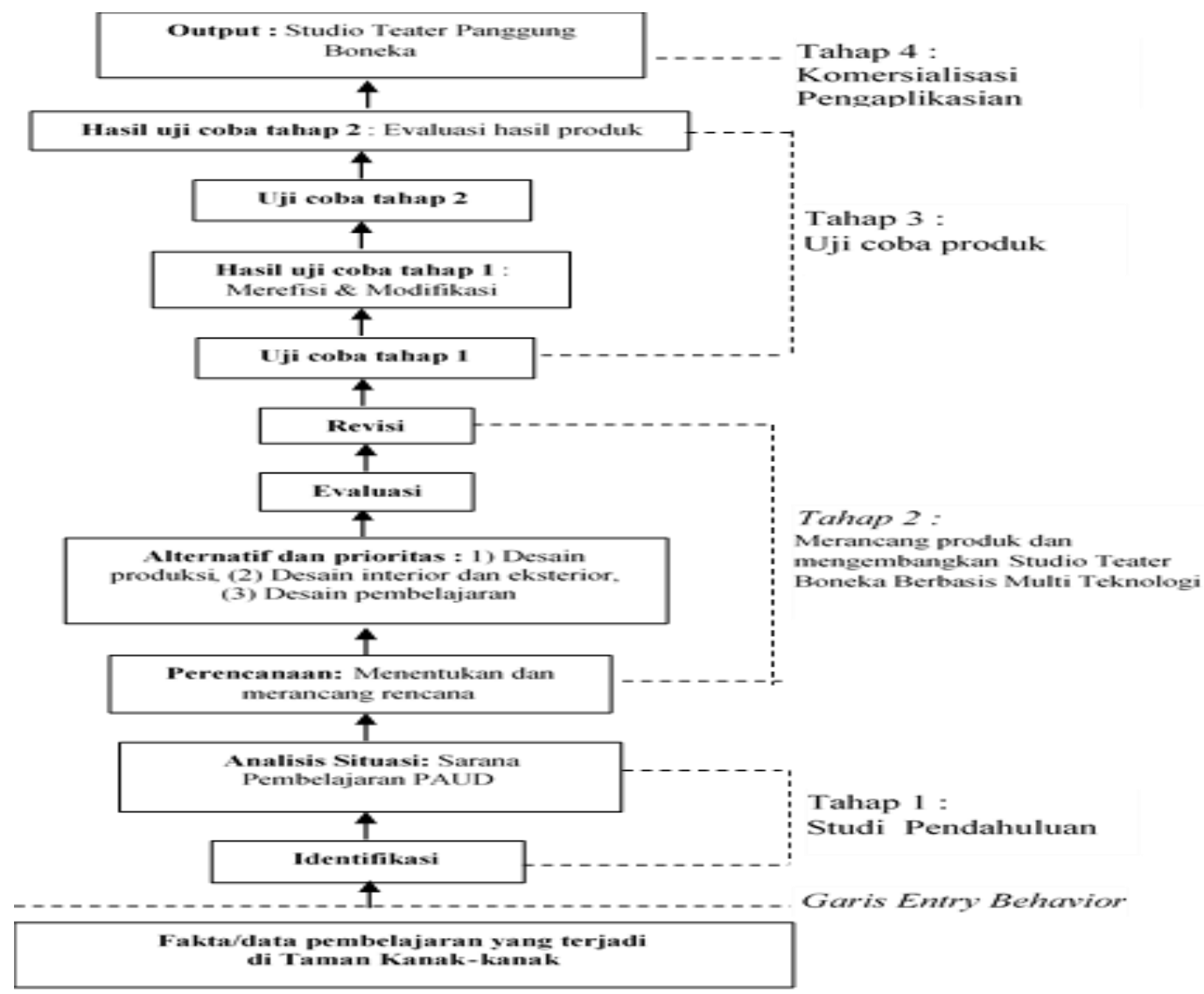

Gambar 1 : Prosedural Pengembangan Studio Teater Panggung Boneka 
Berdasarkan Gambar 1 Prosedural pengembangan Studio Teater Panggung Boneka di awali dengan Fakta/data pembelajaran yang terjadi di Taman Kanak-kanak, kemudian melakukan identifikasi, hasil identifikasi kemudian di analisis kebutuhan yang ditinjau dari Sarana Pembelajaran PAUD, setelah itu dilakukan perencanaan yang bertujuan untuk menentukan dan merancang rencana, selanjutnya alternatif dan perioritas penelitian ini untuk mengebangkan model area drama yaitu Studio Teater Panggung Boneka, kemudian dilakukan uji coba tahap 1 untuk melihat keunggulan dan kelemahan, hasil uji coba tahap 1 dilaksanakan dengan cara merevisi dan memodifikasi Studio Teater Panggung Boneka, selanjutnya bila masih ada kelemahan produk maka dilakukan uji coba tahap 2 untuk melihat sejauh mana produk yang direvisi dan dimodifikasi. Kemudian selanjutnya dilakukan Hasil uji coba tahap 2 dengan mengevaluasi hasil produk. Sampai pada Output Produk Studio Teater Panggung Boneka.

\section{HASIL DAN PEMBAHASAN}

Hasil dan pembahasan pada bagian ini menguraikan hasil pengembangan penelitian Studio Teater Panggung Boneka yang dilakukan dalam empat langkah utama yaitu Studi Pendahuluan, Merancang dan mengembangkan produk, Uji coba produk dan Pengaplikasian Studio Teater Panggung Boneka. Berikut diuraikan hasil temuan dalam penelitian ini sebagai berikut :

\section{Studi Pendahuluan}

Sarana Pembelajaran PAUD merupakan seperangkat alat dan bahan penunjang. Hasil temuan APE Alat Permainan Edukatif dalam ruangan (indoor) area drama dengan kondisi Sarana Pembelajaran PAUD dapat dilihat pada Tabel 1 sebagai berikut:

\section{Tabel 1: Kondisi Sarana Pembelajaran PAUD}

\begin{tabular}{|l|l|}
\hline \multicolumn{1}{|c|}{ Jenis APE dalam Area Drama } & \\
\hline $\begin{array}{l}\text { Peralatan masak-masak } \\
\text { Boneka-bonekaan }\end{array}$ & Rusak Ringan (masih dapat digunakan \\
\hline $\begin{array}{l}\text { Tempat jemuran kecil } \\
\text { Meja kursi kecil }\end{array}$ & Baik \\
\hline Keranjang belanja & Rusak Ringan (masih dapat digunakan \\
\hline $\begin{array}{l}\text { Sayur dan buah mainan } \\
\text { Rumah-rumahan }\end{array}$ & Rusak Ringan (masih dapat digunakan \\
\hline $\begin{array}{l}\text { Mobil-mobilan } \\
\text { Peralatan mandi mainan }\end{array}$ & Rusak Ringan (masih dapat digunakan \\
\hline $\begin{array}{l}\text { Peralatan make up } \\
\text { Mainan tempat tidur }\end{array}$ & Rusak Ringan (masih dapat digunakan \\
\hline Baju profesi & Rusak Ringan (masih dapat digunakan \\
\hline
\end{tabular}


Berdasarkan Tabel 1 Kondisi sarana pembelajaran PAUD di Taman Kanak-kanak masih tergolong minim, hal ini menunjukkan jenis APE dalam area drama hanya 5 kondisi baik dan 7 rusak ringan (masih dapat digunakan). Jenis APE di atas masih minim dan belum berdasarkan pada kaidah sarana pembelajaran PAUD.

Hasil wawancara guru dan anak didik yang dilakukan peneliti tentang sarana pembelajaran PAUD pada Area Drama, guru masih kesulitan dalam membuat anak melakukan permainan boneka, selain itu guru kesulitan mengembangkan sarana pembelajaran pada Area Drama sehingga menyebabkan tidak optimal, guru kesulitan mendesain dan membuat panggung pentas boneka serta terbatasnya pengetahuan, keterampilan dan kreativitas guru dalam area drama.

Selama ini guru PAUD hanya melakukan kegiatan pembelajaran di Area Drama tanpa memperhatikan dan mengembangkan sarana pembelajaran PAUD. Untuk itu diperlukan pengembangan APE dalam bentuk Studio Teater Panggung Boneka sebagai sarana pembelajaran PAUD di Kota Palopo. Sehingga untuk mengatasi masalah utama yang terjadi perlu dimaksimalkan untuk menunjang peningkatan akses dan mutu layanan PAUD di Kota Palopo

Temuan dalam pembelajaran pada anak didik dipengaruhi dua faktor yang dapat mempengaruhi hasil belajar anak didik yakni dipengaruhi dari representasi internal dan eksternal. Representasi internal tidak tersedianya sarana belajar pada area drama dalam melakukan permainan boneka, anak mengalami kesulitan sehingga dapat mempengaruhi capaian pembelajaran yg tidak optimal. Representasi eksternal juga dipengaruhi dari lingkungan keluarga, masyarakat dan sekolah. Di lembaga PAUD masih memiliki keterbatasan dalam penyediaan sarana di area drama dalam permainan boneka. Untuk itu sarana pembelajaran PAUD belum optimal.

\section{Merancang dan Mengembangkan}

Hasil studi pendahuluan meliputi identifikasi masalah, kemudian melakukan Analisis Situasi dengan memperhatikan Karakteristik anak didik dan Persiapan Belajar pada anak. Berikut langkah-langkah desain produksi Studio Teater Panggung Boneka sebagai berikut:

1. Tahap Merancang :

a. Gambar pola panggung dengan sisi depan, belakang, bawah, atas, sisi kiri, sisi kanan.

b. Gambar pola dinding panggung bagian depan dan belakang dinding panggung 
2. Tahap Persiapan : Alat yang digunakan yaitu gurinda, Pensil Bangunan, Meteran rol, Kunci Baut, Bor listrik, Kuas. Bahan yang digunakan yaitu besi siku lubang satu set dengan siku L dengan mor baut, roda trolley, tripleks, mata bor, mata gerinda pemotong besi dan pemotong kayu. Kertas, Cat, Tenner, isolasi Diko. Stiker hiasan, lampu downlight led sorot, kabel dan stok kontak, kain, perekat kain, resleting sepanjang 100, pengikat kabel ties.

3. Tahap Pembuatan Rangka Panggung :

a. 1 batang siku dengan panjang $300 \mathrm{~cm}$. Ambil 2 batang besi siku lubang kemudian ukur dan potong besi siku lubang dengan panjang $150 \mathrm{~cm}$ hingga menjadi 4 potongan.

b. Ambil 2 batang besi siku lubang kemudian ukur dan potong besi siku lubang dengan panjang 1 meter hingga menjadi 4 potongan.

c. Ambil 2 batang besi siku lubang kemudian ukur dan potong besi siku lubang dengan panjang $150 \mathrm{~cm}$ meter hingga menjadi 4 potongan.

d. Rakit menjadi kotak persegi. Untuk merakit diperlukan kunci baut, mor baut, siku L, jika sudah selesai untuk bagian bawah pasang 4 roda

e. Kemudian ambil 2 batang besi siku lubang dan potong dengan panjang 3 meter, pasang 1 pada bagian depan dengan tinggi $100 \mathrm{~cm}, 1$ bilah samping kiri, 1 bilah samping kanan dengan lebar

f. Kemudian ambil 1 batang besi siku lubang dan potong dengan panjang $30 \mathrm{~cm}$ meter, pasang potongan bilah kiri dan kanan dengan ketinggian $100 \mathrm{~cm}$ dan pasang 1 potong yang ukuran 3 meter diantara bilah kiri dan kanan dengan ketinggian $130 \mathrm{~cm}$

4. Tahap Pemasangan Dinding Panggung :

a. Selanjutnya buat pola dinding bagian depan panggung dan belakang panggung, kemudian gergaji menggunakan gurinda. Setelah selesai kemudian pasang bagin dinding depan dan belakang.

b. Lukis pada dinding depan dan belakang panggung dengan menggunakan kuas, cat, tenner, isolasi diko, bila sudah kering pasangkan stiker sesuai dengan keinginan.

\section{Tahap Pendekoran :}

a. $\quad$ Pasang lampu downlight led sorot dengan menggunakan pengikat kabel ties sampai pada pasang kabel dan stok kontak.

b. Ukur kain dan pasang perekat, resleting untuk bagian belakang panggung, jahit pinggir kain, jahit perekat bagian atas keliling, jahit resleting untuk bagian belakang. 
6. Tahap Finishing : Proses akhir penyelesaian Studio Teater Panggung Boneka dengan memastikan panggung boneka dengan mengecek kondisi panggung boneka mini siap di uji cobakan.

Desain produksi Studio Teater Panggung Boneka di atas, kemudian selanjutnya desain interior dan eksterior yang dimodifikasi sebagai berikut:

1. Tirai panggung yang berwarna hitam di tengah-tengahnya dapat dibuka resleting, bagian kiri tirai dapat digeser ke kiri dan bagian kanan tirai dapat digeser ke kanan. Tujuannya dibuka tirai untuk melihat interior dinding bagian belakang dan dijadikan sebagai walpaper pementasan.

2. Bila ditutup tirai panggung yang bewarna hitam, dapat difungsikan ruang untuk menampilkan boneka tali dan di depan panggung terlihat boneka tali dan pemain tidak terlihat.

3. Di belakang bagian dinding depan, terdapat lubang yang bertujuan untuk dapat menancapkan stik pada boneka wayang.

4. Selain boneka tali dan boneka wayang, studio teater boneka juga dapat digunakan dalam permainan boneka jari, boneka tangan yang dimasukkan dari bawah dan boneka tangan yang dimasukkan dari belakang.

5. Di dalam studio teater boneka terdapat lampu sorot dengan posisi bagian sudut kiri atas dan sudut kanan atas. Tujuannya agar dalam pementasan tidak terlihat gelap.

6. Di dalam studio tersedia mikrofon speaker. Tujuannya agar terdengar suara dalam pementasan.

7. Studio tampak samping dan belakang. ditutup dengan tirai agar pemain tidak terlihat dalam pementasan.

8. Panggung memiliki roda dan tuas yang dapat dipindahkan

9. Ruangan studio dapat memuat lima orang anak

Berdasarkan desain produksi dan desain interior dan eksterior, Studio Teater Panggung Boneka diuraikan tahap-tahap desain pembelajaran yaitu sebagai berikut:

1. Tahap 1: Asesmen Awal: pengkondisian sebelum permainan boneka menggunakan area drama

2. Tahap 2: Bila ditampilkan dengan sendiri 
3. Tahap 3: Bila ditampilkan lebih dari 1 pemain yatu media boneka sama tetapi karakter berbeda. Misyalnya permainan boneka tali, semuanya boneka tali, tetapi karakter boneka tali berbeda.

4. Tahap 4: Bila ditampilkan lebih dari 1 pemain yaitu jenis media boneka tidak sama dan masing-masing karakter berbeda. Misyalnya permainan berkolaborasi dengan boneka tali dengan boneka pupet atau boneka jari dengan boneka tangan, atau semuanya sekaligus.

5. Tahap 5: Asesmen Akhir: pengkondisian setelah permainan boneka menggunakan Studio Teater Boneka Berbasis Multi Teknologi.

6. Tahap 6: Recalling: proses yang diharuskan anak untuk dapat menceritakan pengalaman selama melakukan permainan boneka.

7. Tahap 7: Umpan balik: respon terhadap sesuatu yang ditimbulkan dari komunikator tentang pengalaman yang dilakukannya dalam permainan boneka.

8. Tahap 8: Mengevaluasi: proses pengukuran memberikan penilaian dalam upaya mencapai tujuan pembelajaran dalam permainan boneka.

\section{Validasi APE}

Instrumen pengembangan sarana pembelajaran PAUD di Taman Kanak-kanak yaitu Studio Teater Panggung Boneka diperiksa dengan melalui uji pakar ahli (Expert Judgment) yang memiliki wawasan keilmuan tentang Arsitek dan Mendongeng sehingga konsep instrumen dapat dipercaya dan dapat di uji cobakan dalam penelitian ini. Indikator penilaian disusun berdasarkan desain produksi, desain interior dan eksterior, desain pembelajaran.

Hasil validasi pakar arsitek menunjukkan bahwa (1) desain produksi dengan skor maksimal dengan nilai 80 memperoleh perolehan sebesar 72 dengan persentase $90 \%$ menunjukkan kategori layak; (2) desain interior dan eksterior dengan skor maksimal dengan nilai 80 memperoleh perolehan sebesar 75 dengan persentase 94\% menunjukkan kategori layak; (3) desain pembelajaran dengan skor maksimal dengan nilai 100 memperoleh perolehan sebesar 95 dengan persentase 95\% menunjukkan kategori layak. Hasil validasi pakar arsitek secara keseluruhan memperoleh skor 242 dengan persentase 93\% dengan kategori layak. Adapun detail penilainnya terlihat pada Tabel 2 sebagai berikut: 


\section{Tabel 2 : Hasil Validasi Pakar Arsitek}

\begin{tabular}{|l|c|c|c|c|}
\hline \multicolumn{1}{|c|}{ Indikator Penilaian } & Skor Maks & Skor Perolehan & Persentase & Kategori \\
\hline Desain Produksi & 80 & 72 & $90 \%$ & Layak \\
\hline Desain interior dan eksterior & 80 & 75 & $94 \%$ & Layak \\
\hline Desain pembelajaran & 100 & 95 & $95 \%$ & Layak \\
\hline \multicolumn{1}{|c|}{ Skor } & 260 & 242 & $93 \%$ & Layak \\
\hline
\end{tabular}

Sedangkan dari Hasil validasi pakar pendongeng berdasarkan tiga indikator penilaian hasil penilainnya terlihat pada Tabel 3 yaitu sebagai berikut:

\section{Tabel 3 : Hasil Validasi Pakar Pendongeng}

\begin{tabular}{|l|c|c|c|c|}
\hline \multicolumn{1}{|c|}{ Indikator Penilaian } & Skor Maks & Skor Perolehan & Persentase & Kategori \\
\hline Desain Produksi & 80 & 76 & $95 \%$ & Layak \\
\hline Desain interior dan eksterior & 80 & 73 & $91 \%$ & Layak \\
\hline Desain pembelajaran & 100 & 90 & $90 \%$ & Layak \\
\hline \multicolumn{1}{|c|}{ Skor } & 260 & 239 & $92 \%$ & Layak \\
\hline
\end{tabular}

Berdasarkan Tabel 3 menunjukkan bahwa (1) desain produksi dengan skor maksimal dengan nilai 80 memperoleh perolehan sebesar 76 dengan persentase 95\% menunjukkan kategori layak; (2) desain interior dan eksterior dengan skor maksimal dengan nilai 80 memperoleh perolehan sebesar 73 dengan persentase 91\% menunjukkan kategori layak; (3) desain pembelajaran dengan skor maksimal dengan nilai 100 memperoleh perolehan sebesar 90 dengan persentase 90\% menunjukkan kategori layak. Hasil validasi pakar pendongeng secara keseluruhan memperoleh skor 239 dengan persentase 92\% dengan kategori layak.

Pengembangan APE dalam memenuhi sarana pembelajaran PAUD bertumpu pada peningkatan tujuan pendidikan di satuan PAUD. Untuk itu APE dikembangkan dan dijadikan sebagai sarana pembelajaran PAUD di Kota Palopo. Pengembangan tersebut dilakukan beberapa tahapan yang diadopsi dari Borg dan Gall (1983: 772) yang diawali Studi 
Pendahuluan, Merancang dan mengembangkan produk, Uji coba produk, dan sampai dengan Komersialisasi Pengaplikasian.

Pengembangan Studio Teater Panggung Boneka didasari dengan tiga hal yaitu desain produksi, desain interior dan eksterior, dan desain pembelajaran. Rancangan tersebut, dapat digunakan untuk menyalurkan informasi atau materi pengajaran melalui melalui indera pandang (visual) dan indera pandang-dengar (audio visual) yang dapat merangsang pikiran, perasaan, perhatian dan minat belajar antara sumber pesan ke penerima pesan dalam memperoleh pengetahuan, sikap, dan keterampilan (Ramli, Syamsul Alam, 2014). Untuk itu kegiatan pembelajaran harus disukai dan sangat disenangi anak didik (Anita Yus, 2012). Kemudian dikemas menarik hingga menjadi hal yang menyenangkan (Nur Fathonah dan Erlin Ladyawati, 2016).

Studio Teater Panggung Boneka dibuat sesuai standar sarana pembelajaran PAUD. Pengembangan APE ini dapat memberikan pengetahuan dan pengalaman dalam mengembangkan kreatifitas anak (Natalivea, 2009).

Berdasarkan penelitian Pengembangan Studio Teater Panggung Boneka layak diterapkan untuk meningkatkan akses dan mutu layanan PAUD dan meningkatkan kemampuan lembaga PAUD dalam penyediaan dan pengembangan sarana pembelajaan dengan memanfaatkan bahan dan budaya lokal.

Dengan demikian Studio Teater Panggung Boneka dapat dijadikan sebagai alternatif sarana pembalajaran PAUD di Taman Kanak-kanak serta pengembanganya sesuai standar sarana pembelajaran PAUD.

\section{SIMPULAN}

Studio Teater Panggung Boneka adalah seluruh panggung yang berbentuk ruang dan didalamnya terdapat tempat untuk memainkan boneka, latar, dan area untuk mementaskan pertunjukan boneka. Studio Teater Panggung Boneka dapat menjadikan anak didik dapat bermain boneka di dalam studio teater dan mengaktualisasikan permainan boneka pada pertunjukan boneka. Studio Teater Panggung Boneka dapat dijadikan sebagai alternatif media pembelajaran sebagai sarana pembalajaran PAUD serta pengembanganya sesuai standar sarana pembelajaran PAUD di Taman Kanak-kanak Kota Palopo.

Studio Teater Boneka Berbasis Multi Teknologi adalah Alat Permainan Edukatif yang di desain dalam bentuk media pembelajaran. Untuk mengembangkan didasari dengan tiga hal yaitu desain produksi, desain interior dan eksterior, dan desain pembelajaran. 
Pengembangannya diawali Studi Pendahuluan, Merancang dan mengembangkan produk, Uji coba produk, dan sampai dengan Komersialisasi Pengaplikasian.

Pengembangan Studio Teater Boneka Berbasis Multi Teknologi memberikan manfaat yaitu pertama, menunjang peningkatan akses dan mutu layanan PAUD; kedua, meningkatkan kemampuan lembaga dalam penyediaan dan pengembangan sarana pembelajaan dengan memanfaatkan bahan dan budaya lokal di Kota Palopo sebagai kota hinterland.

\section{DAFTAR PUSTAKA}

Aniendya Christianna, (2013) Pelatihan Perencanan APE Berbasis Bahan Bekas Untuk PAUD dalam SHARE, Vol. 1, No. 1.

Anita Yus. (2012). Penilaian Perkembangan Belajar Anak Taman Kanak-Kanak. Jakarta: Kencana Prenada Media Group.

Dirjen PAUD dan Pendidikan Masyarakat. (2018). Petunjuk Teknis Bantuan Sarana Pembelajaran/Alat permainan Edukatif PAUD No. 09 tahun 2018. Kemendikbud.

Ditjen PAUDNI. (2013). Petunjuk Teknis Bantuan Sarana Pembelajaran PAUD. Kemendikbud.

Hari Sunaryo, dkk., (2016). Desain Media Pembelajaran Keterampilan Bersastra Berbasis Panggung. SenasPro: UMM.

J. Bessant, Managing Avanced Manufakturing Technology: the Challenge of the Fithy Wave, NCC-Blackwell, Manchester, 1991, dikutip dari J. Bessant and H. Rush, 1995, Building bridges for innovation: the role of consultants in technology transfer, Research Policy, Vol. 24, No.1, Januari, hal.104.

KBBI. (2018). Studio. Dalam https://kbbi.web.id/studio.html, diakses tanggal 07 Juli 2018.

KBBI. (2018). Teater. Dalam https://kbbi.web.id/teater.html, diakses tanggal 07 Juli 2018.

Montolalu, dkk. (2009). Bermain dan Permainan Anak. Jakarta: Universitas Terbuka.

Myrnawati Crie Handini. (2012). Metodelogi Penelitian Untuk Pemula. Jakarta: FIP Press.

Nana Sudjana \& Ahmad Rivai. (2007). Media Pengajaran. Bandung: Sinar Baru lgensindo.

Nur Fathonah dan Erlin Ladyawati. (2016). Implementasi Media Pembelajaran Edukatif Untuk POS PAUD Terpadu Surabaya dalam Jurnal WAHANA Vol. 67 (2).

Ondroadi, Natalivea (2009) Perancangan interior House of Barbie di Surabaya. Bachelor thesis, Petra Christian University.

Permendikbud 137. (2014). Standar Tingkat Pencapaian Perkembangan Anak. Jakarta: Permendikbud.

Ramli, Syamsul Alam. (2014). Pengaruh Media Pembelajaran Audio Visual dan Literasi Membaca Terhadap Hasil Belajar Sains. Jakarta:UNJ. 
Rustan. (2018). Komunikasi Verbal Anak Pesisir Usia 7-8 Tahun Pada Transaksi Penjualan Produk Kebudayaan Dengan Turis Mancanegara dalam Jurnal Pendidikan Anak Usia Dini Vol 12 No. 1, 14. 